Supporting Information

\title{
A Salt Stimulus-Responsive Nanohydrogel for Controlled \\ Fishing Low-density lipoprotein with Superior Adsorption \\ Capacity
}

Jian-Fang Cao, Wang Xu, Yao-Yao Zhang, Yang Shu*, Jian-Hua Wang*

Department of Chemistry, College of Sciences, Northeastern University, Shenyang 110819, China.

*Corresponding author.

E-mail:shuyang@mail.neu.edu.cn; jianhuajrz@mail.neu.edu.cn

Tel: 86-24-83688944 


\section{EXPERIMENTAL SECTION}

Chemicals and reagents. Tetraethyl orthosilicate (TEOS), (3-aminopropyl) triethoxysilane (APTES, $\geq 99 \%$ ), succinic anhydride, N-(3-(dimethylamino) propyl)-N'-ethyl carbodiimide hydrochloride (EDC $\cdot \mathrm{HCl}, 98 \%)$, N-hydroxysuccinimide (NHS, 98\%), 2-(N-morpholino) ethanesulfonic acid monohydrate (MES $\cdot \mathrm{H}_{2} \mathrm{O}, 99 \%$ ), and magnesium chloride hexahydrate $\left(\mathrm{MgCl}_{2} \cdot 6 \mathrm{H}_{2} \mathrm{O}\right)$ are purchased from Aladdin (Shanghai, China). Ammonia aqueous solution $\left(\mathrm{NH}_{3} \cdot \mathrm{H}_{2} \mathrm{O}, 25-28 \%\right)$ and ethanol are obtained from Sinopharm Chemical Reagent Co., Ltd (Shanghai, China). The monomers of N, N'-methylenebisacrylamide (MBA, 97\%), 3-AminopropenenHydrochloride (AH, >98\%) and 3-\{(2 (Methacryloyloxy)ethyl)(dimethyl)ammonio \}-1-propanesulfonate (DMAPS, 97\%), are purchased from Sigma-Aldrich (St. Louis, USA) without further purification. The initiator, azodiisobutyronitrile (AIBN, 99\%), is obtained from Aladdin Chemistry Co. Ltd. (Shanghai, China). Tween 80, Span 80, and Chondroitin sulfate (CS) are purchased from Shanghai Yuanye Biotechnology Co., Ltd. (Shanghai, China).

Bovine serum albumin (BSA, A3311, 98\%), $\beta$-lactoglobulin ( $\beta$-Lg, L39008, 90\%), and $\alpha$-lactalbumin (a-LA, M1882, 90\%) are acquired from Sigma-Aldrich (St. Louis, USA). Human Low-density lipoprotein (LDL) is obtained from Yiyuan Biotech (Guangzhou, China). Human serum samples are provided by healthy volunteers. All reagents are at least of analytical reagent grade and used without further purification. Deionized (DI) water of $18 \mathrm{M} \Omega$ is used throughout.

Instrumentations. Scanning electron microscopy (SEM) images and Energy-dispersive X-ray (EDS) mapping images are collected on a LEO1430VP Scanning Electron Microscope (LEO, Germany). All samples are dried and sprayed with a thin gold layer before performing SEM. Fourier transform infrared spectra (FTIR) are collected from a Nicolet-6700 infrared spectrometer (Thermo Ltd, Waltham, America). X-ray photoelectron spectroscopy (XPS) measurements are recorded by a Thermo Scientific ESCALAB 250Xi electron spectrometer (Thermo Electron, America). Thermogravimetric analysis is conducted on a TGA/DSC3+ 
analyzer (TGA, Mettler-Toledo, Switzerland) with a heating rate of $10{ }^{\circ} \mathrm{C} \mathrm{min}-1$ under protection with nitrogen. Zeta potential measurements are carried out by dynamic light scattering (DLS) with a Nano ZS90 (Malvern, U.K.). Circular dichroism (CD) spectra are obtained on a MOS-450 (Bio-Logic, France) automatic recording spectropolarimeter at $293 \mathrm{~K}$ with nitrogen protection. A PB-10 pH Meter (Beijing Sartorius Instruments Co., Ltd., China) is used for pH monitoring. F-7000 fluorescence spectrophotometer (Hitachi High-Technologies Corporation, Japan) is used for the quantitative detection of protein.

The calculation of adsorption efficiency and elution efficiency. The supernatant is measured to quantify the residual protein content. The adsorption efficiency is calculated according to the following equation Eq. 1, where $\mathrm{E}, \mathrm{C}_{0}$, and $\mathrm{C}_{1}$ represent the adsorption efficiency, the protein concentrations in the original solution, and residual protein concentrations, respectively.

$$
E=\frac{C_{0}-C_{1}}{C_{0}} \times 100 \%
$$

\section{Eq. 1}

The supernatant after centrifugation at $6000 \mathrm{rpm}$ for $6 \mathrm{~min}$ is collected for evaluating the elution efficiency $\left(E^{\prime}\right)$ by following equation Eq. 2, where $\mathrm{C}_{2}, \mathrm{C}_{0}$, and $\mathrm{C}_{1}$ represent the protein concentration in the supernatant after the desorption process, the protein concentrations in the original solution, and residual protein concentrations, respectively.

$$
E^{\prime}=\frac{C_{2}}{C_{0}-C_{1}} \times 100 \%
$$

Eq. 2 

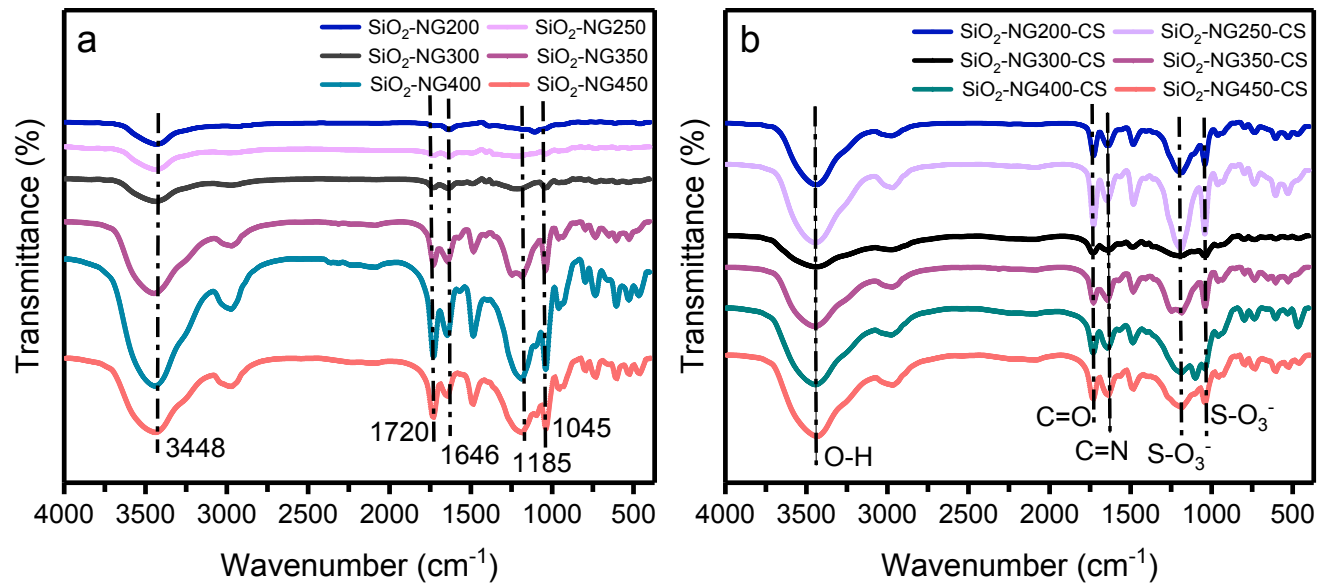

Figure S1. FTIR spectra of $\mathrm{SiO}_{2}-\mathrm{NGs}$ nanoparticles containing various amounts of NGs (200, 250, 300, 350, 400 and $450 \mathrm{mg}$ ) (a); FT-IR spectra of $\mathrm{SiO}_{2}$-NGs-CS nanoparticles containing various amount of NGs $(200,250,300,350,400$ and 450 mg) (b). 


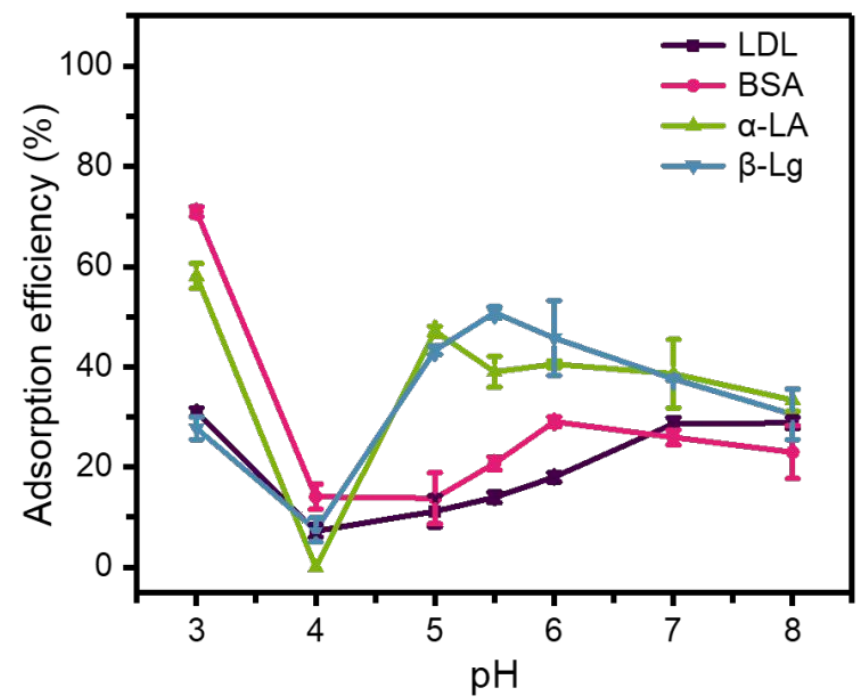

Figure S2. The adsorption behaviors of LDL, BSA, $\alpha-\mathrm{LA}$, and $\beta$-Lg on the surface of $\mathrm{SiO}_{2}-\mathrm{NG} 350-\mathrm{CS}$ in B-R buffer solution within $\mathrm{pH}$ 3-8. Protein solution: $300 \mathrm{~mL}, 15$ $\mathrm{mg} \mathrm{mL} \mathrm{mL}^{-1}$. Adsorption time: $30 \mathrm{~min}$. Mass of adsorbent: $0.3 \mathrm{mg}$. 

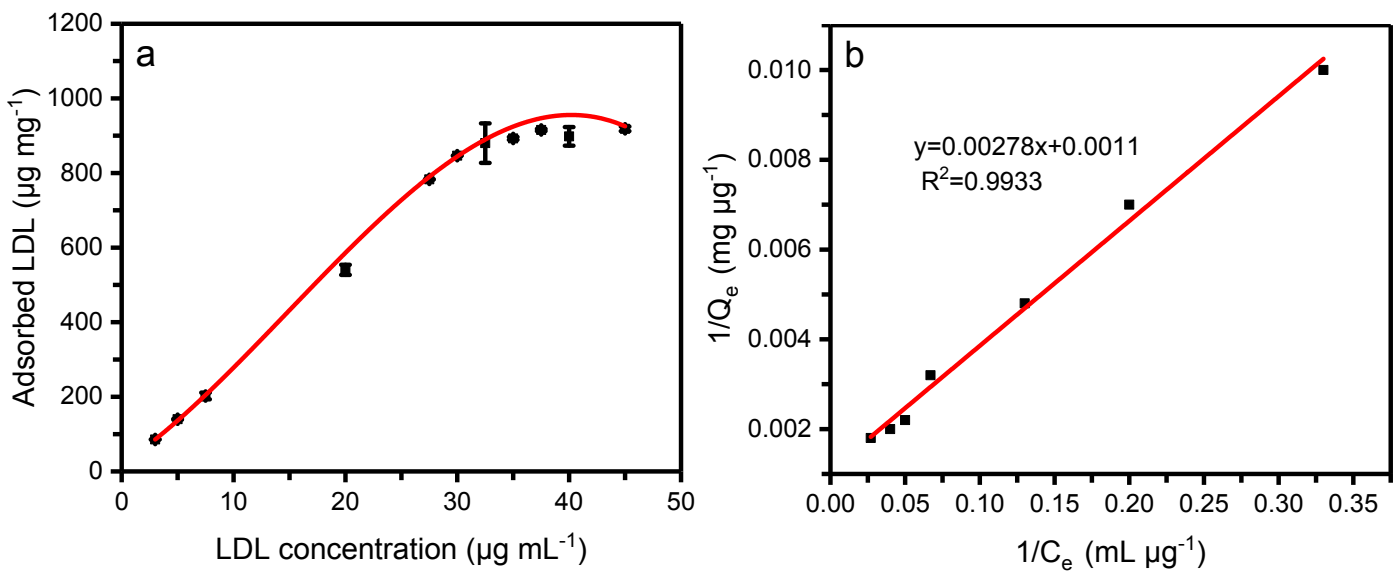

Figure S3. Adsorption isotherm of $\mathrm{LDL}$ by $\mathrm{SiO}_{2}-\mathrm{NG} 350-\mathrm{CS}$ at $\mathrm{pH} 4.0$ (a) and plot of $1 / \mathrm{Q}_{\mathrm{e}}$ versus $1 / \mathrm{C}_{\mathrm{e}}(\mathrm{b})$. 

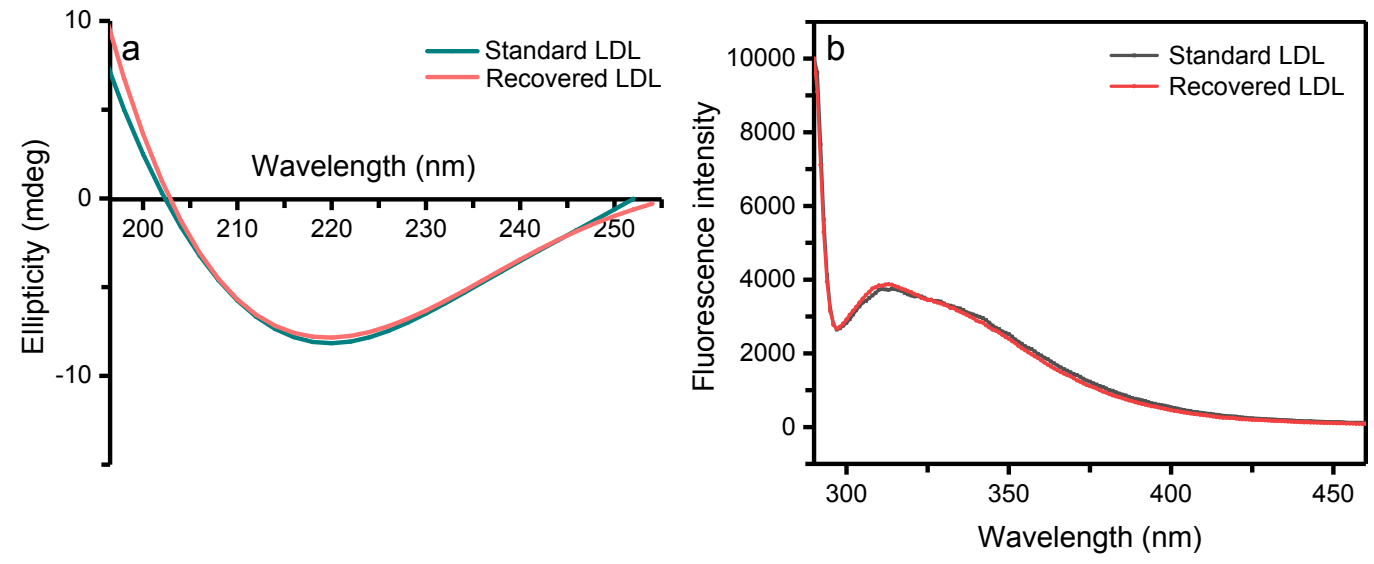

Figure S4. CD spectra (a) and fluorescence spectra (b) of the standard LDL solution and recovered LDL with the $\mathrm{SiO}_{2}-\mathrm{NG} 350-\mathrm{CS}$. 
Table S1. Adsorption capacities for LDL with various adsorbents

\begin{tabular}{|c|c|c|c|c|}
\hline Adsorbent & $\begin{array}{l}\text { Adsorption } \\
\text { Capacity } \\
\left(\mu \mathrm{g} \mathrm{mg}^{-1}\right)\end{array}$ & Interference & Ref. & $\begin{array}{l}\text { Adsorption } \\
\text { functional } \\
\text { groups/molecules }\end{array}$ \\
\hline $\mathrm{Fe}_{3} \mathrm{O}_{4}-\mathrm{PM}_{1} \mathrm{~S}_{1}$ & 7 & BSA & 1 & $\begin{array}{l}\text { Saccharide and } \\
\text { sulfonate units }\end{array}$ \\
\hline $\begin{array}{l}\text { Heparin } \\
\text { immobilized } \\
\text { Cellulose Gel beads }\end{array}$ & 79.1 & HDL & 2 & $\begin{array}{l}\text { Sulfonic groups and } \\
\text { carboxyl groups }\end{array}$ \\
\hline $\begin{array}{l}\text { Carrageenan Based } \\
\text { Heparin Mimetic } \\
\text { Gel Beads }\end{array}$ & 18.15 & $\begin{array}{l}\text { BSA and } \\
\text { BFG }\end{array}$ & 3 & $\begin{array}{l}\text { Polysaccharide } \\
\text { structure, } \\
\text { sulfonic and } \\
\text { carboxyl groups }\end{array}$ \\
\hline $\begin{array}{l}\text { Sulfonated } \\
\text { CNTs/activated } \\
\text { carbon composite } \\
\text { beads }\end{array}$ & 10.46 & Not clear & 4 & $\begin{array}{l}\text { Sulfonic groups and } \\
\text { carboxyl groups }\end{array}$ \\
\hline MNPs@CS@Hep & 1.04 & $\begin{array}{l}\text { HDL and } \\
\text { total } \\
\text { cholesteol }\end{array}$ & 5 & $\begin{array}{l}\text { Heparin and } \\
\text { chitosan }\end{array}$ \\
\hline ADC-20 & 816.7 & $\begin{array}{l}\text { BSA, } \alpha-L A, \beta- \\
\text { Lg }\end{array}$ & 6 & $\begin{array}{l}\text { Polysaccharide } \\
\text { structure } \\
\text { and sulfonic groups }\end{array}$ \\
\hline $\mathrm{SiO}_{2}-\mathrm{NG} 350-\mathrm{CS}$ & 898.1 & $\begin{array}{l}\text { BSA, } \alpha-L A, \beta- \\
\text { Lg }\end{array}$ & $\begin{array}{l}\text { This } \\
\text { work }\end{array}$ & $\begin{array}{l}\text { Polysaccharide } \\
\text { structure and } \\
\text { sulfonic groups }\end{array}$ \\
\hline
\end{tabular}


Table S2. The recovery of cholesterol measured with Phosphorus-sulphur-iron method.

\begin{tabular}{llll}
\hline $\begin{array}{l}\text { LDL original } \\
\text { concentration }(\mu \mathrm{g} \\
\left.\mathrm{mL}^{-1}\right)\end{array}$ & $\begin{array}{l}\text { The percentage of cholesterol } \\
\text { before adsorption/desorption } \\
\text { process }\end{array}$ & $\begin{array}{l}\text { The percentage of } \\
\text { cholesterol after } \\
\text { adsorption/desorption } \\
\text { process }\end{array}$ & $\begin{array}{l}\text { The recovery } \\
\text { percentage }\end{array}$ \\
\hline 5 & $63.3 \%$ & $60.4 \%$ & $95.4 \%$ \\
10 & $57.8 \%$ & $53.0 \%$ & $91.7 \%$ \\
15 & $52.8 \%$ & $50.6 \%$ & $95.8 \%$ \\
\hline
\end{tabular}




\section{References}

(1) Cheng, K.; Li, Y. C.; Cai, H. J.; Xu, X. Y.; Zhao, W. F.; Zhang, D. Y.; Zhao, C. S.; Li, J. $\mathrm{S}$. Chondroitin-analogue decorated magnetic nanoparticles via a click reaction for selective adsorption of low-density lipoprotein. Polymer Chemistry 2019, 10, 2540-2550.

(2) Li, Y. P.; Han, M.; Wang, Y. L.; Liu, Q.; Zhao, W. F.; Su, B. H.; Zhao, C. S. A mussel-inspired approach towards heparin-immobilized cellulose gel beads for selective removal of low density lipoprotein from whole blood. Carbohydrate Polymers 2018, 202, 116-124.

(3) Song, X.; Wang, K.; Tang, C. Q.; Yang, W. W.; Zhao, W. F.; Zhao, C. S. Design of Carrageenan-Based Heparin-Mimetic Gel Beads as Self-Anticoagulant Hemoperfusion Adsorbents, Biomacromolecules 2018, 19, 1966-1978.

(4) Lu, Y. M.; Gong, Q. M.; Lu, F. P.; Liang, J.; Ji, L. J.; Nie, Q. D.; Zhang, X. M. Preparation of sulfonated porous carbon nanotubes/activated carbon composite beads and their adsorption of low density lipoprotein. J Mater Sci Mater Med 2011, 22, 1855-1862.

(5) Li, J. H.; Hou, Y. H.; Chen, X. Y.; Ding, X. W.; Liu, Y.; Shen, X. K.; Cai, K. Y. Recyclable heparin and chitosan conjugated magnetic nanocomposites for selective removal of low-density lipoprotein from plasma. J Mater Sci Mater Med 2014, 25, 1055-1064.

(6) Cao, J. F.; Xu, W.; Chen, X. W.; Shu, Y. Improvement on the extraction efficiency of low density lipoprotein in an ionic liquid microemulsion. Talanta 2019, 195, 720-727. 